BIO-Oceans Association announces the publication of a major treatise reviewing the history and marine research accomplishments at Canada's Bedford Institute of Oceanography over five decades primarily in the Atlantic and Arctic Oceans.

\title{
Voyage of Discovery Fifty Years of Marine Research at Canada's Bedford Institute of Oceanography
}

\author{
Edited by D.N. Nettleship, D.C. Gordon, \\ C.F.M. Lewis and M.P. Latremouille
}

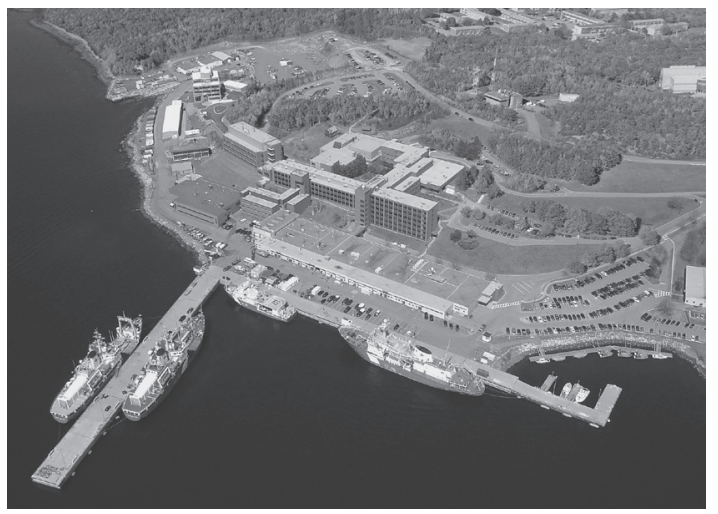

A commemorative volume in celebration of the 50th Anniversary of BIO: 1962 - 2012

VOYAGE OF DISCOVERY summarizes BIO research results on the oceanography of Arctic and Eastern Canada. In a series of 48 papers by past and present research staff from all oceanographic disciplines at BIO, the history of Canadian oceanography before BIO and a broad cross section of the Institute's work spanning five decades are featured with particular emphasis on contributions to Canadian and global understanding/management of the marine environment.

Divided into 12 sections with a Preface and Epilogue,Voyage of DiscoverY is the most extensive overview of the history and scientific accomplishments of the Bedford Institute of Oceanography under one cover: Historical Roots, Arctic Studies, Ocean Life, Ocean Circulation and Chemistry, Hydrography and Seabed Mapping, Geological Oceanography, Fisheries-Ecosystems-Aquaculture, Marine Contamination, Technology and Instrument Development, Energy Developments, BIO and the Law of the Sea, and The BIO Experience. This book's well-written and illustrated accounts will appeal to a broad readership from professional oceanographers and environmental/resource managers and decision-makers to marine science students and lay persons interested in the Arctic and Atlantic oceans, and their present status and future welfare. 


\section{VOYAGE OF DISCOVERY}

Hardcover, text on premium $8.5 \times 11$ inch glossy 100 lb Sterling paper with sewn binding

460 pages, $2.2 \mathrm{~kg}$.

Price: $\$ 35.00 \mathrm{Cdn} /$ US plus shipping

ISBN 978-0-9936443-0-6

BIO-OA Publication: October 2014

\section{ORDER FORM}

To order one or more copies of Voyage of Discovery, please complete order form below and send with payment (money order, cheque, credit card) or purchase order (for libraries, institutions, universities) to: BIO-Oceans Association (VOD), c/o Bedford Institute of Oceanography, P.O. Box 1006, Dartmouth, Nova Scotia, Canada B2Y 4 A2.

Please send me copies of Voyage of Discovery

$\$ 35$ Cdn/US per copy (\$36 if charged to credit card) plus shipping (mailer \& postage) if not picked up at BIO.

Shipping costs: Atlantic Canada, \$13; Quebec \& Ontario, \$15; MB, SK, $A B$ and BC, \$17; Territories, \$24; United States, \$26; Europe, \$34; and elsewhere, \$39.

Amount: \$ Cdn/US

Manner of delivery: $\square$ pickup at BIO $\square$ send by mail

Method of payment:

$\square$ I enclose cheque/money order (payable to BIO-Oceans Association)

$\square$ Pay by credit card (circle type): VISA MC AMEX JCB Discover Acct \#

Expiry Date Security Code

Postal/Zip Code on billing address for card Name on card

Delivery name and address:

Name:

Address:

E-mail address:

With many thanks for your order from BIO-Oceans Association 